\title{
Isolation of multiple drug-resistant enteric bacteria from feces of wild Western Lowland Gorilla (Gorilla gorilla gorilla) in Gabon
}

\author{
Pierre Philippe MBEHANG NGUEMA ${ }^{1)}$,Torahiko OKUBO ${ }^{2)}$, Sayaka TSUCHIDA ${ }^{3)}$, Shiho FUJITA ${ }^{4)}$, \\ Juichi YAMAGIWA ${ }^{5)}$, Yutaka TAMURA ${ }^{2)}$ and Kazunari USHIDA ${ }^{3) *}$ \\ ${ }^{1)}$ Research Institute of Tropical Ecology, Libreville, Bp 13354, Libreville, Gabon \\ ${ }^{2)}$ Laboratory of Food Microbiology and Food Safety, Department of Health and Environmental Sciences, School of Veterinary Medicine, \\ Rakuno Gakuen University, Ebetsu, Hokkaido 069-0836, Japan \\ ${ }^{3)}$ Graduate School of Life and Environmental Sciences, Kyoto Prefectural University, Shimogamo, Kyoto 606-8522, Japan \\ 4) United Graduate School of Veterinary Science, Kagoshima University, Kagoshima 890-0065, Japan \\ ${ }^{5}{ }^{5}$ Graduate School of Science, Kyoto University, Kitashirakawa, Kyoto 606-8502, Japan
}

(Received 19 November 2014/Accepted 18 January 2015/Published online in J-STAGE 30 January 2015)

ABSTRACT. Prevalence of drug-resistant bacteria in wildlife can reveal the actual level of anthropological burden on the wildlife. In this study, we isolated two multiple drug-resistant strains, GG6-2 and GG6-1-1, from 27 fresh feces of wild western lowland gorillas in MoukalabaDoudou National Park, Gabon. Isolates were identified as Achromobacter xylosoxidans and Providencia sp., respectively. Minimum inhibitory concentrations of the following 12 drugs - ampicillin (ABPC), cefazolin (CEZ), cefotaxime (CTX), streptomycin (SM), gentamicin (GM), kanamycin (KM), tetracycline (TC), nalidixic acid (NA), ciprofloxacin (CPFX), colistin (CL), chloramphenicol (CP) and trimethoprim (TMP) - were determined. Isolate GG6-2 was resistant to all antimicrobials tested and highly resistant to CTX, SM, TC, NA and TMP. Isolate GG6-1-1 was resistant to ABPC, CEZ, TC, CL, CP and TMP.

KEY WORDS: intestinal bacteria, multiple drug-resistance, wild gorilla

doi: 10.1292/jvms.14-0604; J. Vet. Med. Sci. 77(5): 619-623, 2015

A multidisciplinary study has been conducted on the ecosystems of the tropical forest in Moukalaba-Doudou National Park (MDNP), Gabon, since 2009 [21]. Our studies focused on the conservation of biodiversity in the tropical forest through sustainable coexistence between humans and wild animals. In tourism that targets endangered wild animals, such as the gorilla, it is important to reduce the human impact on the wildlife [13]. Transmission of human-borne microbes, especially pathogens, to wild animals must be controlled in this context.

In addition to viral, bacterial and protozoal pathogens [19], we studied the distribution of drug-resistant bacteria in wild gorillas. Since the emergence and spread of antibioticresistant bacteria was caused by humans [11], we thought that the level of drug-resistant bacteria in wildlife might reveal the actual level of the anthropological burden on the wildlife in MDNP.

In a preliminary survey, we have detected a range of antibiotic-resistant genes from the fecal Enterobacteriaceae of wild gorillas in MDNP [22]. The most prevalent genes were responsible for resistance against $\beta$-lactam antibiotics. This is not surprising, because some species of Enterobacteriaceae naturally harbor such resistance [14]. The second

*Correspondence to: Ushida, K., Graduate School of Life and Environmental Sciences, Kyoto Prefectural University, Shimogamo, Kyoto 606-8522, Japan. e-mail: k_ushida@kpu.ac.jp

(C2015 The Japanese Society of Veterinary Science

This is an open-access article distributed under the terms of the Creative Commons Attribution Non-Commercial No Derivatives (by-nc-nd) License $<$ http://creativecommons.org/licenses/by-nc-nd/3.0/>. most prevalent gene was aminoglycoside-resistance genes, followed by genes responsible for tetracycline resistance and chloramphenicol resistance. It was also suggested that some of the isolates hosted multiple resistances. We presumed that it would not be plausible for wild animals in MDNP to be free from antibiotic-resistant enterobacteria of anthropological origin. MDNP was once exploited by a logging company with more than 1,000 employees living in bunkhouses surrounding the forest. After the logging operations were withdrawn in 1989, a group of the bunkhouses became villages, and a crop plantation surrounds the forest; therefore, the wild animals in MDNP may have contact with humans in close proximity. In this study, we tried to isolate multidrug-resistant enterobacteria from wild gorillas in MDNP to measure the level of anthropological impact on wild animals in MDNP before the full-scale introduction of tourism in this forest.

Feces of wild western lowland gorillas were collected during research trips organized in August and December 2013 and in February 2014. In total, 20 fresh feces were sampled randomly from 4 groups of gorillas and one solitary individual in the summer of 2013 in the forest of Boutsiana and Mt. Doudou in MDNP. Four more feces were sampled in December 2013, and 3 fresh feces were sampled in February 2014 in the forest of Moukalaba in MDNP. The location of the sampling site was shown elsewhere [33]. The fecal samples were collected and inoculated on the plate media as described previously [36]. Briefly, fresh gorilla feces were sampled by localization and subsequent following the groups of gorillas or solitaires with a distance of ca. 15-20 m which enable to collect fecal samples just after 
Table 1. Summary of sampling results

\begin{tabular}{llccc}
\hline Period & $\begin{array}{c}\text { Sampling location } \\
\text { in MDNP }\end{array}$ & $\begin{array}{c}\text { Number of } \\
\text { feces collected }\end{array}$ & $\begin{array}{c}\text { Number of colonies } \\
\text { developed }\end{array}$ & $\begin{array}{c}\text { Number of feces carrying } \\
\text { resistant bacteria }\end{array}$ \\
\hline Aug-13 & Boutsiana & 10 & 3 & $3^{\text {a) }}$ \\
Aug-13 & Mt. Doudou & 10 & 0 & 0 \\
Dec-13 & Moukalaba & 4 & 3 & $3^{\text {b) }}$ \\
Feb-14 & Boutsiana & 3 & 2 & 1 \\
\hline
\end{tabular}

a): GG6-2 was purified; b): GG6-1-1 was purified. The locations are shown elsewhere [33].

Table 2. Identification, antimicrobial susceptibility and resistance genes of 2 isolates

\begin{tabular}{|c|c|c|c|c|c|c|c|c|c|c|c|c|c|c|}
\hline \multirow{2}{*}{ Strain } & \multirow{2}{*}{ Identification $^{\text {a) }}$} & \multicolumn{12}{|c|}{$\operatorname{MIC}(\mu \mathrm{g} / \mathrm{m} l)^{\mathrm{b})}$} & \multirow{2}{*}{$\begin{array}{c}\text { Resistance } \\
\text { Gene }^{\text {c) }}\end{array}$} \\
\hline & & $\mathrm{ABPC}$ & CEZ & CTX & SM & GM & KM & $\mathrm{TC}$ & NA & CPFX & $\mathrm{CL}$ & $\mathrm{CP}$ & TMP & \\
\hline GG6-2 & $\begin{array}{l}\text { Achromobacter } \\
\text { xylosoxidans }\end{array}$ & 32 & 128 & $>64$ & $>128$ & 32 & 64 & $>64$ & 128 & 2 & 2 & 32 & $>16$ & N.D. \\
\hline GG6-1-1 & Providencia sp. & 32 & $>128$ & $\leq 0.5$ & 8 & 4 & 2 & 64 & 4 & $\leq 0.03$ & $>16$ & 32 & 16 & $\operatorname{tet} B$ \\
\hline
\end{tabular}

a): Identified by $16 \mathrm{~S}$ rRNA gene sequences. Accession numbers are LC009440 and LC009441. b): Abbreviations and the range of antimicrobial concentration $(\mu \mathrm{g} / \mathrm{m} l)$ in MIC testing are as follows: ABPC, ampicillin (1-128); CEZ, cefazolin (1-128); CTX, cefotaxime (0.5-64); SM, streptomycin (1-128); GM, gentamicin (0.5-64); KM, kanamycin (1-128); TC, tetracycline (0.5-64); NA, nalidixic acid (1-128); CPFX, ciprofloxacin (0.03-4); CL, colistin (0.12-16); CP, chloramphenicol (1-128); and TMP, trimethoprim (0.25-16). c): Results from PCR amplification with specific primers for $b l a_{\mathrm{TEM}}, b l a_{\mathrm{SHV}}, b l a_{\mathrm{CTX}-\mathrm{M}}$, plasmid-mediated $\mathrm{AmpC}$, tet $A$, tet $B$, tetC, tet $D$, tetE and tet $G$. N.D., not detected.

defecation. A loopful of feces was placed on tryptic-soy agar (TSA) (Tryptic Soy Broth (Becton, Dickinson and Co., Sparks, MD, U.S.A.) supplemented with $1.5 \%$ agar) plates supplemented with defibrinated horse blood $(5 \% \mathrm{v} / \mathrm{v})$ and a mixture of antibiotics (ampicillin, tetracycline, gentamycin and chloramphenicol with final concentrations at $4 \mu \mathrm{g} / \mathrm{m} l$ ) that corresponded to the major resistance genes detected in the previous survey and the major class of antibiotics used in Gabon thus far. After returning to the camp site, the fecal specimen on the plate was streaked and placed in a styrene foam box with hand warmers to keep the temperature in the box as close as possible to $37^{\circ} \mathrm{C}$. After visible colonies were grown (up to $48 \mathrm{hr}$ incubation), the plates were placed in a dark, cool place or in a water stream beside the camp site for safer preservation. After returning to the laboratory in Libreville, colonies were picked and transferred to the fresh TSA plates supplemented with antibiotics at the same concentration. For the preliminary identification, DNA was extracted from single colony of each isolate by DNA Stool Mini Kit (QIAGEN, Tokyo, Japan), and resultant DNA solutions were transported to Kyoto for partial sequencing (ca. $500 \mathrm{bps}$ ) of 16S rRNA gene as indicated elsewhere [35]. After species level identification, two isolates were transported to Japan by a commercial parcel service for further analyses.

After receipt of these bacteria in Japan, DNA was again isolated from these bacteria with the DNA Stool Mini Kit, and 16S rRNA genes were amplified with primers $63 \mathrm{f}$ and 1387r [20]. Amplicons were subjected to direct sequencing at FASMAC Co., Ltd. (Atsugi, Japan) by the dye-terminator method. A range of resistance genes was examined by PCR amplification. The PCR protocol was the same as indicated elsewhere [16, 17, 24, 37]. The drug susceptibility of the isolates was determined according to the Clinical and Laboratory Standards Institute (CLSI) with the Performance
Standards for Antimicrobial Susceptibility Testing (M31A3) [9]. Briefly, Dry Plate ${ }^{\circledR}$ (Eiken Chemical, Tokyo, Japan) was applied to determine the minimum inhibitory concentrations (MIC) of the following 12 drugs: ampicillin (ABPC), cefazolin (CEZ), cefotaxime (CTX), streptomycin (SM), gentamycin (GM), kanamycin (KM), tetracycline (TC), nalidixic acid (NA), ciprofloxacin (CPFX), colistin (CL), chloramphenicol (CP) and trimethoprim (TMP). Bacteria were suspended in McFarland No. 1 with Tryptosoy Bouillon Medium (Eiken Chemical) and further mixed with MuellerHinton Bouillon Medium (Eiken Chemical) and inoculated in plate wells to obtain $2.5 \times 10^{4} \mathrm{CFU} /$ well. The plates were incubated at $37^{\circ} \mathrm{C}$ for $18 \mathrm{hr}$ in ambient air. Growth was checked visually according to the manufacturer's instructions. MIC breakpoints used for GG6-1-1 and GG6-2 were those established by CLSI for Enterobacteriaceae [10] and other non-Enterobacteriaceae, such as Achromobacter, respectively $[2,10]$.

In the summer of 2013 survey, we detected three colonies on the plates from three individual fecal samples. Among these three colonies, two of them were contaminated by yeast and mobile Gram staining negative bacteria. These two colonies could not be purified through repeated transfers to fresh TSA plates with antibiotics. The remaining colony, designated as GG6-2, was, therefore, subjected to a further study (Table 1). In the 2013-2014 survey, we have detected 5 colonies from 7 fecal samples; however, as in the 2013 research trip, one colony was only obtained as a purified enterobacterial isolate. This isolate was designated as GG6-1-1 (Table 1).

Two gorilla isolates, both Gram staining negative rods, GG6-2 and GG6-1-1, were, respectively, identified as Achromobacter xylosoxidans $(1,261 \mathrm{bp} / 1,261 \mathrm{bp}$, identity $=100 \%)$ and Providencia sp. $(1,274 \mathrm{bp} / 1,278 \mathrm{bp}$, identity=99\%). 
The latter is highly similar to $P$. rettgeri $(1,273 / 1,278 \mathrm{bp}$, identity $=99 \%$ ) in its $16 \mathrm{~S}$ rRNA gene sequences. Their $16 \mathrm{~S}$ rRNA gene sequences were registered at the DNA Database of Japan (DDBJ) with accession numbers LC009440 and LC009441, respectively.

Achromobacter spp. are considered to be environmental bacteria [3, 23]. However, this group of bacteria was detected in a wide range of clinical specimens, including feces, and was recognized as human nosocomial bacterium [1, 3, 5]. As shown in Table 2, isolate GG6-2 was resistant to all antimicrobials tested and highly resistant to CTX, SM, TC, NA and TMP. Achromobacter naturally harbors various $\beta$-lactamase including AmpC type [15]. It is obvious that strain GG6-2 showed innate resistance to ABPC. This isolate also showed resistance to third-generation cephalosporin as well as to aminoglycosides and tetracycline. A. xylosoxidans has been shown to be innately resistant to cephalothin, cefoxitin, cefotaxime, aztreonam and aminoglycosides [5, 6]. Acquired resistance to carbapenems, ceftazidime and ciprofloxacin is also frequent $[3,4,18]$. In addition to these resistances, our isolate harbors tetracycline resistance and chloramphenicol resistance.

Isolate GG6-1-1 was resistant to ABPC, CEZ, TC, CL, $\mathrm{CP}$ and TMP, but susceptible to aminoglycosides and quinolones. Providencia also naturally harbors AmpC-type $\beta$-lactamase [14]. Because of its susceptibility to CTX, it is expected that GG6-1-1 is naturally resistant to ABPC and CEZ. In addition to $\beta$-lactam, clinical isolates of $P$. stuartii are innately resistant to tetracycline with varying resistance to aminoglycosides [31]. GG6-1-1 is close to P. rettgeri, which has multi-drug resistance to a lesser extent as compared with $P$. stuartii [31].

Isolates GG6-2 and GG6-1-1 showed resistance to tetracycline and aminoglycoside as well as to $\beta$-lactam. The resistance of GG6-1-1 shown in Table 2 is regarded as innate, according to the literature [31], and its susceptibility to CTX and CPFX suggests that this strain has characteristics in common with $P$. rettgeri. However, in the case of GG6-2, high resistance to the third-generation cephalosporin, CTX, was shown. At present, we cannot conclude the origin of such resistance in GG6-2. It is possible that wild gorillas represent a reservoir of multi-drug resistance, as discussed elsewhere $[12,25,26,28,32]$. As shown in a study in a remote area of Africa, the glacier snow samples from Mt. Stanley of Ruwenzori, Uganda, contained high levels of resistance genes to carbapenem (blaIMP), chloramphenicol $(\mathrm{cmr} A)$ and tetracycline (tet $G)$, followed by resistance genes to aminoglycoside $(\operatorname{aac}(3), \operatorname{aac} \mathrm{C}$ and $\operatorname{str} A)$; the bacteria harboring the resistance genes may have spread out all over the African continent through global atmospheric circulation [30]. Moreover, A. xylosoxidans is commonly detected in various environments [23]. In this circumstance, wild gorillas could acquire several resistant bacteria to exhibit multidrug resistance in their digestive tracts. In fact, Benavides et al. [7], who surveyed the prevalence of antibiotic-resistant Escherichia coli in wild gorillas and villagers living adjacent to the Lopé National Park in Gabon, concluded that there was no or very low direct transmission of resistant E. coli from humans to wild gorillas in Lopé National Park. However, the anthropological burden of gorillas in MDNP is not the same for those in Lopé National Park; the human population density around Lopé was 4 times lower $(0.2$ person/ $\left.\mathrm{km}^{2}\right)$ than that around MDNP $\left(0.8\right.$ person $\left./ \mathrm{km}^{2}\right)[8,34]$; the latter had intensive logging activity along with agricultural activity. It is, therefore, not safe to exclude the transmission of human-borne resistant bacteria in MDNP as suggested by Cohen [11], who concluded that the emergence and spread of multidrug-resistant enterobacteria is, in principle, considered human-borne. Acquisition of resistance to 3rd-generation cephalosporin supports this hypothesis. In fact, there were several surveys regarding the antibiotic resistance of infectious bacteria in 1997 and 2009 in a hospital located adjacent to MDNP that clearly indicated a significant progress in the resistance of diarrheagenic E. coli isolates to secondgeneration cephalosporin, third-generation cephalosporin, carbapenem, aminoglycosides and the new quinolones [27, 29]. The multidrug-resistant Achromobacter presently found in gorillas together with previously suggested resistant Enterobacter and Klebsiella [22] in wild western lowland gorillas may suggest that gorillas in Gabon have been exposed to human-borne resistant bacteria. Although the prevalence of multi-drug resistant bacteria was not high (Table 1), wild animals like gorilla in MDNP may have received the stronger anthropological influences comparing to those in Lopé National Park in terms of transmission of bacteria.

ACKNOWLEDGMENTS. This study was conducted as part of the PROCOBHA (Prof. Juichi Yamagiwa) supported by SATREPS program (Japan Science and Technology Agency and Japan International Cooperation Agency). The authors thank Jean Manfoumbi Nzahou, Christian Nzoutsy Kelly, Jonas Ndoudi, Guy Roger Doukaga, Stephanie Matsanga and Jean Constant Obague Mbeang for their help with collecting fresh feces in MDNP.

\section{REFERENCES}

1. Aisenberg, G., Rolston, K. V. and Safdar, A. 2004. Bacteremia caused by Achromobacter and Alcaligenes species in 46 patients with cancer (1989-2003). Cancer 101: 2134-2140. [Medline] [CrossRef]

2. Almuzara, M., Limansky, A., Ballerini, V., Galanternik, L., Famiglietti, A. and Vay, C. 2010. In vitro susceptibility of Achromobacter spp. isolates: comparison of disk diffusion, Etest and agar dilution methods. Int. J. Antimicrob. Agents 35: 68-71. [Medline] [CrossRef]

3. Amoureux, L., Bador, J., Fardeheb, S., Mabille, C., Couchot, C., Massip, C., Salignon, A. L., Berlie, G., Varin, V. and Neuwirth, C. 2013. Detection of Achromobacter xylosoxidans in hospital, domestic, and outdoor environmental samples and comparison with human clinical isolates. Appl. Environ. Microbiol. 79: 7142-7149. [Medline] [CrossRef]

4. Amoureux, L., Bador, J., Siebor, E., Taillefumier, N., Fanton, A. and Neuwirth, C. 2013. Epidemiology and resistance of Achromobacter xylosoxidans from cystic fibrosis patients in Dijon, Burgundy: First French data. J. Cyst. Fibros. 12: 170-176. [Medline] [CrossRef]

5. Bador, J., Amoureux, L., Duez, J. M., Drabowicz, A., Siebor, 
E., Llanes, C. and Neuwirth, C. 2011. First description of an RND-type multidrug efflux pump in Achromobacter xylosoxidans, AxyABM. Antimicrob. Agents Chemother. 55: 4912-4914. [Medline] [CrossRef]

6. Bador, J., Amoureux, L., Blanc, E. and Neuwirth, C. 2013. Innate aminoglycoside resistance of Achromobacter xylosoxidans is due to AxyXY-OprZ, an RND-type multidrug efflux pump. Antimicrob. Agents Chemother. 57: 603-605. [Medline] [CrossRef]

7. Benavides, J. A., Godreuil, S., Bodenham, R., Ratiarison, S., Devos, C., Petretto, M. O., Raymond, M. and Escobar-Páramo, P. 2012. No evidence for transmission of antibiotic-resistant Escherichia coli strains from humans to wild western lowland gorillas in Lope National Park, Gabon. Appl. Environ. Microbiol. 78: 4281-4287. [Medline] [CrossRef]

8. Blom, A., Christy, P., Ntchandi-Otimbo, P. A. and Vande weghe, J. P. 2003. Les Aires Protégées: Parc National de la Lopé. Observatoire des Forets d'Afrique Centrales (OFAC). http:// www.observatoire-comifac.net/pa.php? country $=\mathrm{GAB} \& \mathrm{pa}=6$ (in French).

9. Clinical and Laboratory Standards Institute. 2011. Performance standards for antimicrobial and dilution susceptibility tests for bacteria isolated from animals; approved standard. 3rd ed. CLSI document M31-A3. Clinical and Laboratory Standards Institute, Wayne.

10. Clinical and Laboratory Standards Institute. 2011. Performance standards for antimicrobial susceptibility testing: twenty-first informational supplement. CLSI document M100-S21. Clinical and Laboratory Standards Institute, Wayne.

11. Cohen, M. L. 1992. Epidemiology of drug resistance: Implications for a post-antimicrobial era. Science 257: 1050-1055. [Medline] [CrossRef]

12. Cole, D., Drum, D. J., Stalknecht, D. E., White, D. G., Lee, M. D., Ayers, S., Sobsey, M. and Maurer, J. J. 2005. Free-living Canada geese and antimicrobial resistance. Emerg. Infect. Dis. 11: 935-938. [Medline] [CrossRef]

13. Homsy, J. 1999. Tourisme, grands singes et maladies humaines: Où est la limite? Rapport d'une Consultation pour le Programme International pour la Conservation des Gorilles (PICG), Rwanda. http://www.primate-sg.org/storage/pdf/Homsy_1999_francais. pdf (in French).

14. Jacoby, G. A. 2009. AmpC beta-lactamases. Clin. Microbiol. Rev. 22: 161-182. [Medline] [CrossRef]

15. Jakobsen, T.H., Hansen, M.A., Jensen, P. Ø., Hansen, L., Riber, L., Cockburn, A., Kolpen, M., Hansen, C.R., Ridderberg, W., Eickhardt, S., Hansen, M., Kerpedjiev, P., Alhede, M., Qvortrup, K., Burmølle, M., Moser, C., Kühl, M., Ciofu, O., Givskov, M., Sørensen, S.J., Høiby, N. and Bjarnsholt, T. 2013. Complete Genome Sequence of the Cystic Fibrosis Pathogen Achromobacter xylosoxidans NH44784-1996 Complies with Important Pathogenic Phenotypes. PLoS ONE DOI: [CrossRef]. [Medline]

16. Jun, L. J., Jeong, J. B., Huh, M. D., Chung, J. K., Choi, D. L., Lee, C. H. and Jeong, H. D. 2004. Detection of tetracycline-resistance determinants by multiplex polymerase chain reaction in Edwardsiella tarda isolated from fish farms in Korea. J. Aquat. 27: 89-100.

17. Kojima, A., Ishii, Y., Ishihara, K., Esaki, H., Asai, T., Oda, C., Tamura, Y., Takahashi, T. and Yamaguchi, K. 2005. Extendedspectrum-beta-lactamase-producing Escherichia coli strains isolated from farm animals from 1999 to 2002: Report from the Japanese Veterinary Antimicrobial Resistance Monitoring Program. Antimicrobial Resistance Monitoring Program. Antimicrob. Agents Chemother. 49: 3533-3537. [Medline] [CrossRef]

18. Lambiase, A., Catania, M. R., DelPezzo, M., Rossano, F., Terl- izzi, V., Sepe, A. and Raia, V. 2011. Achromobacter xylosoxidans respiratory tract infection in cystic fibrosis patients. Eur. J. Clin. Microbiol. Infect. Dis. 30: 973-980. [Medline] [CrossRef]

19. Makouloutou, P., Mbehang Nguema, P. P., Fujita, S., Takenoshita, Y., Hasegawa, H., Yanagida, T. and Sato, H. 2014. Prevalence and genetic diversity of Oesophagostomum stephanostomum in wild lowland gorillas at Moukalaba-Doudou National Park, Gabon. Helminthologia 51: 83-93. [CrossRef]

20. Marchesi, J. R., Sato, T., Weightman, A. J., Martin, T. A., Fry, J. C., Hiom, S. J., Dymock, D. and Wade, W. G. 1998. Design and evaluation of useful bacterium-specific PCR primers that amplify genes coding for bacterial 16S rRNA. Appl. Environ. Microbiol. 64: 795-799. [Medline]

21. Matsuura, N., Takenoshita, Y. and Yamagiwa, J. 2014. Ecological anthropology and primatology for biodiversity conservation: A collaborative project in Moukalaba-Doudou National Park in Gabon. Rev. Primatol. 5: http://primatologie.revues. org/1775DOI: 10.4000/primatologie.1775 (in French).

22. Mbehang Nguma, P. P., Tsuchida, S. and Ushida, K. 2015. Bacteria culturing and isolation under field conditions of MoukalabaDoudou National Park, Gabon, and preliminary survey on bacteria carrying antibiotic resistance genes. Tropics. 23: 165-174.

23. Neuwirth, C., Freby, C., Ogier-Desserrey, A., Perez-Martin, S., Houzel, A., Péchinot, A., Duez, J. M., Huet, F. and Siebor, E. 2006. VEB-1 in Achromobacter xylosoxidans from cystic fibrosis patient, France. Emerg. Infect. Dis. 12: 1737-1739. [Medline] [CrossRef]

24. Pérez-Pérez, F. J. and Hanson, N. D. 2002. Detection of plasmidmediated AmpC beta-lactamase genes in clinical isolates by using multiplex PCR. J. Clin. Microbiol. 40: 2153-2162. [Medline] [CrossRef]

25. Poeta, P., Radhouani, H., Igrejas, G., Gonçalves, A., Carvalho, C., Rodrigues, J., Vinué, L., Somalo, S. and Torres, C. 2008. Seagulls of the Berlengas natural reserve of Portugal as carriers of fecal Escherichia coli harboring CTX-M and TEM extended-spectrum $\beta$-lactamases. Appl. Environ. Microbiol. 74: 7439-7441. [Medline] [CrossRef]

26. Poeta, P., Radhouani, H., Pinto, L., Martinho, A., Rego, V., Rodrigues, R., Gonçalves, A., Rodrigues, J., Estepa, V., Torres, C. and Igrejas, G. 2009. Wild boars as reservoirs of extendedspectrum beta-lactamase (ESBL) producing Escherichia coli of different phylogenetic groups. J. Basic Microbiol. 49: 584-588. [Medline] [CrossRef]

27. Presterl, E., Zwick, R. H., Reichmann, S., Aichelburg, A., Winkler, S., Kremsner, P. G. and Graninger, W. 2003. Frequency and virulence properties of diarrheagenic Escherichia coli in children with diarrhea in Gabon. Am. J. Trop. Med. Hyg. 69: 406-410. [Medline]

28. Radhouani, H., Poeta, P., Gonçalves, A., Pacheco, R., Sargo, R. and Igrejas, G. 2012. Wild birds as biological indicators of environmental pollution: Antimicrobial resistance patterns of Escherichia coli and enterococci isolated from common buzzards (Buteo buteo). J. Med. Microbiol. 61: 837-843. [Medline] [CrossRef]

29. Scherbaum, M., Kösters, K., Mürbeth, R. E., Ngoa, U. A., Kremsner, P. G., Lell, B. and Alabi, A. 2014. Incidence, pathogens and resistance patterns of nosocomial infections at a rural hospital in Gabon. BMC Infect. Dis. 14: 124. [Medline] [CrossRef]

30. Segawa, T., Takeuchi, N., Rivera, A., Yamada, A., Yoshimura, Y., Barcaza, G., Shinbori, K., Motoyama, H., Kohshima, S. and Ushida, K. 2013. Distribution of antibiotic resistance genes in glacier environments. Environ. Microbiol. Rep. 5: 127-134. [Medline] [CrossRef] 
31. Stock, I. and Wiedemann, B. 1998. Natural antibiotic susceptibility of Providencia stuartii, P. rettgeri, P. alcalifaciens and $P$. rustigianii strains. J. Med. Microbiol. 47: 629-642. [Medline] [CrossRef]

32. Su, H., McKelvey, J., Rollins, D., Zhang, M., Brightsmith, D. J., Derr, J. and Zhang, S. 2014. Cultivable bacterial microbiota of northern bobwhite (Colinus virginianus): A new reservoir of antimicrobial resistance? PLOS ONE 9: e99826. [Medline] [CrossRef]

33. Takenoshita, Y. and Yamagiwa, J. 2008. Estimating gorilla abundance by dung count in the northern part of Moukalaba-Doudou National Park, Gabon. Afr. Study Monogr. 39: 41-54.

34. Thibault, M. and Blaney, S. 2003. The oil industry as an underlying factor in the bushmeat crisis in central Africa. Conserv. Biol. 17: 1807-1813. [CrossRef]
35. Tsukahara, T. and Ushida, K. 2002. Succinate accumulation in pig large intestine during antibiotic-associated diarrhea and the constitution of succinate-producing flora. J. Gen. Appl. Microbiol. 48: 143-154. [Medline] [CrossRef]

36. Tsuchida, S., Takahashi, S., Mbehang Nguema, P. P., Fujita, S., Kitahara, M., Yamagiwa, J., Ngomanda, A., Ohkuma, M. and Ushida, K. 2014. Bifidobacterium moukalabense sp. nov. isolated from the faeces of wild west lowland gorilla (Gorilla gorilla gorilla) in Gabon. Int. J. Syst. Evol. Microbiol. 64: 449-455. [Medline] [CrossRef]

37. Xu, L., Ensor, V., Gossain, S., Nye, K. and Hawkey, P. 2005. Rapid and simple detection of blaCTX-M genes by multiplex PCR assay. J. Med. Microbiol. 54: 1183-1187. [Medline] [CrossRef] 